\title{
ENTREPRENEURSHIP EDUCATION IN HIGHER EDUCATION: OPTIMIZING INNOVATIVE BEHAVIOUR OF Z GENERATION
}

\author{
Dodi Wirawan Irawanto*) and Khusnul Rofida Novianti**)1 \\ ${ }^{*}$ Department of Management, Faculty of Economics and Business, Brawijaya University \\ Jl. Veteran Malang, 65145, Malang, Indonesia \\ ${ }^{* *}$ Department of Management, Faculty of Economics and Business, University of Muhammadiyah Malang \\ Jl. Raya Tlogomas No.246, 65144, Malang, Indonesia
}

\begin{abstract}
Generation $\mathrm{Z}$ and its contribution in the formal and informal sectors are starting to appear. This is inseparable from the MSME sector, where generation $\mathrm{Z}$ brings a new result-oriented work pattern with the optimization of technology and information. In higher education, carrying out a response to the 4.0 industrial revolution requires universities to prepare gen $Z$ students to adapt to this environment. This study aims to explore how the perceptions of gen $Z$ students regarding entrepreneurship education in higher education by seeing whether it has an impact on innovative behavior. Basic research on survey research in tertiary institutions in Malang City has a mission focus on entrepreneurial spirit, namely Brawijaya University, UIN Maulana Malik Ibrahim, and the University of Muhammadiyah Malang 175 respondents and analyzed using multiple regression analysis. The result shows that entrepreneurship education with a pedagogic approach significantly affects innovative behavior, differs from the alternative approach. This research is expected to contribute to the current model of entrepreneurship education formulation.
\end{abstract}

Keywords: entrepreneurship, entrepreneurship education, innovation, generation z, higher education

Abstrak: Generasi $Z$ dan kontribusinya di sektor formal maupun informal mulai terlihat eksistensinya. Hal ini tidak terlepas dari sektor UMKM, dimana generasi $Z$ membawa pola kerja baru yang berorientasi pada hasil dengan optimalisasi teknologi dan informasi. Perguruan tinggi, dengan mengusung responsifitasnya terhadap revolusi industri 4.0 menuntut perguruan tinggi untuk menyiapkan mahasiswa utamanya gen $Z$ untuk adaptif dengan lingkungan tersebut. Penelitian ini bertujuan untuk mengeksplorasi bagaimanakah persepsi mahasiswa gen $Z$ tentang pendidikan kewirausahaan di perguruan tinggi dengan melihat apakah memiliki dampak terhadap perilaku inovatif. Penelitian ini didasarkan pada metode penelitian survey pada perguruan tinggi di Kota Malang yang memiliki fokus misi dalam membentuk jiwa kewirausahaan, yakni Universitas Brawijaya, UIN Maulana Malik Ibrahim dan Universitas Muhammadiyah Malang dengan menggunakan analisis regresi berganda. Hasil menunjukkan bahwa pendidikan kewirausahaan dengan pendekatan pedagogik berpengaruh signifikan terhadap perilaku inovatif, berbeda dengan pendekatan alternatif. Penelitian ini diharapkan dapat memberikan kontribusi pada perumusan model pendidikan kewirausahaan saat ini.

Kata kunci: kewirausahaan, pendidikan kewirausahaan, inovasi, generasi z, pendidikan tinggi

\footnotetext{
${ }^{1}$ Corresponding author:

Email: khusnulrofida@umm.ac.id
} 


\section{INTRODUCTION}

In this today globalized and accessible world, doing business in any mode such as being an entrepreneur is one of the options that Gen $\mathrm{Z}$ could contribute to. Therefore, the demand for entrepreneur education is highly needed, especially for developed countries. Entrepreneurship education has been promoted as a key way of improving the performance of developed countries (Lourenço and Jones, 2006) including Indonesia. In recent years, the idea of entrepreneurship and innovation has gained much more scholarly recognition, and academic programs in this field have begun to be embraced by many universities worldwide. Such data was concentrated on the influence of education and pedagogy for entrepreneurship education. In the early 1970s, much of the research in the area of entrepreneurship and innovation focused on characteristics relating to financial and business planning skills. Yet scholars have turned to other fields of entrepreneurial skills and standards competency related to innovation and entrepreneurship education in recent years. A few other studies have concentrated on the antecedents that establish student entrepreneurial behavior through several entrepreneurial education programs (Fayolle et al. 2006; Fayolle and Gailly, 2015) such as pedagogic and alternative programs.

The study conducted by Lewrick et al. (2011) on entrepreneurship education suggested the task of transforming a company start-up actual business requires skills that go beyond creating a concept and business plan that is typically the curriculum for entrepreneurship programs at the higher education level. In the curriculum of entrepreneurship education, creativity, a sense of initiative, self-confidence, leadership, and team spirit are essential. As a business creates and grows, the role of entrepreneur changes, thus, it is not only important to students to learn knowledge and business skills. Students should be able to handle the transition as the business evolves and personal characteristics are also very important in entrepreneurship education.

Education in entrepreneurship included courses in specialist training centers and universities, as well as self-taught education in further education in management and entrepreneurship education. Studies have shown that the entrepreneurship intention of students and therefore their tendency for entrepreneurial conduct are affected by their attitudes towards entrepreneurship (Van Gelderen et al. 2008). Many other studies have suggested that entrepreneurial intention and behavior can be stimulated by entrepreneur education, in addition to individual factors that shape the entrepreneurial behavior of students. Through their global longitudinal study, Vanevenhoven and Liguori (2013) demonstrated that entrepreneurship education motivates the entrepreneurial intention and behavior of students. Souitaris et al. (2007) have shown that entrepreneurship programs increase business attitude.

It is been clear that previous studies only explore how entrepreneurship education is part of the capacity building for being entrepreneurs, whilst this study explores the two common methods of entrepreneurship education and explores further to what extend that two approaches led to the innovative behavior. Therefore, this study aims to explore the effect between entrepreneurial education (using pedagogic and alternative teaching approach) and see its difference on innovative behavior using data survey from students of three big universities (Brawijaya University, UIN Maulana Malik Ibrahim, and the University of Muhammadiyah Malang) which has a focus mission on developing the entrepreneurial spirit in Malang city.

\section{METHODS}

This study used a survey design optimizing purposive sampling and conducted in three universities in Malang city (Brawijaya University, UIN Maulana Malik Ibrahim, and the University of Muhammadiyah Malang). The data collection method used an online questionnaire sent to the respondent. The study population was the student in the third and fifth semesters in three universities in Malang city who was taken entrepreneurship courses. The respondent criteria are the students who have taken entrepreneurship course and was born on and after 2000. Hair et al. (2014) stated the minimum samples with a variable $\leq$ of 5 should 100 or above, therefore 175 questionnaires were collected and filled. The questionnaire included 54 items related to entrepreneurship education and innovative behavior using a Likert scale ranging from 1 (strongly disagree) to 5 (strongly agree). Entrepreneurship education based on the pedagogic approach mentioned by Lourenço and Jones (2006) consists of 20 items such as problembased learning, learn through an apprenticeship, competition, role play, multi-media case study. Entrepreneurship education based on an alternative 
approach consists of 14 items by Wright, Bitner, and Zeithaml (1994) in Lourenço and Jones (2006) such as constructed by learners, interactive learning activities, and transformative teaching and learning. Innovative behavior using 20 items develop by Saji and Nair (2018). In this study, GPA score and the level of the semester were used as control variables. Hypotheses testing using multiple regression analysis using SPSS 23 software to identify and predict variables that are most important in entrepreneurship education (pedagogic and alternative approach) to innovative behavior.

There are unique subjects of entrepreneurship education and creativity in many of the universities recently. The delivery of entrepreneurship education in a pedagogy model nowadays is a popular way of the entrepreneurship program. Harris, Forbes and Fletcher (2000) argue that the transfer of knowledge and information based on traditional university pedagogy is emphasized by approaches to entrepreneurship education. The pedagogic methods tend to be activity-based where learning is built into the doing process by learners. Based on the empirical facts above, the H1 hypotheses could be proposed as follows:

H1: entrepreneur education using a pedagogic approach affects innovative behavior

Shaw (2004) mentioned that entrepreneurship researchers criticized the traditional approach and led to the emergence of an alternative entrepreneurial approach based on the cognitive learning model to teach entrepreneurship. Learning is complex, involved, positive, and goal-oriented mechanism rather than being passive. In brief, alternative approaches to the education of entrepreneurship use a 'transmissive technique' for teaching and learning is used by 'transformative methodology'(Sterling, 2001). Thus, the proposed hypotheses as follows:

$\mathrm{H} 2$ : entrepreneur education using alternative approach affects innovative behavior

\section{RESULTS}

The following respondent description based on Table 1 can be described as $52 \%$ are female and dominant by aged between $20-25$ in the fifth semester with a good GPA ranged in $3.00-3.50$. Table 2 shows the descriptive statistics and inter-correlations for the four constructs.
Table 1. Respondent demography

\begin{tabular}{llcc}
\hline Particulars & Items & Freq (175) & Percentage (\%) \\
\hline Gender & Male & 85 & 48.3 \\
& Female & 91 & 51.7 \\
University & UB & 65 & 36.9 \\
& UIN & 45 & 25.6 \\
& UMM & 66 & 37.5 \\
Age & $15-20$ & 77 & 43.8 \\
& $20-25$ & 99 & 56.3 \\
Level of & 3 & 76 & 43.7 \\
semester & 5 & 99 & 56.3 \\
GPA score & $<3,00$ & 78 & 44.3 \\
& $>3,00$ & 98 & 55.7 \\
\hline
\end{tabular}

Three tests were run to examine the suitability of the data. First, data validation and reliability. Reliability test used to test the reliability of collected data using Cronbach's alpha. The result shows that the Cronbach's alpha of the variable is 0.838 and the factor load of each item is above 0.5 which indicates that the instrument used is valid and reliable shown in Table 2.

Table 2. Validity and reliability test

\begin{tabular}{lcccc}
\hline & EEP & IB & EEA & $\begin{array}{c}\text { Cronbach } \\
\text { Alpha }\end{array}$ \\
\hline EEP & 1 & $0.629 * *$ & $0.748 * *$ & \\
IB & $0.629 * *$ & 1 & $0.532 * *$ & 0.838 \\
EEA & $0.748 * *$ & $0.532 * *$ & 1 & \\
** correlation is significant at 0.01 level (2-tailed)
\end{tabular}

Second, the data was evaluated to see if it met the normal distribution and no multicollinearity exist. The tolerance value and the variance inflation factor (VIF) were used to assess both pairwise and multicollinearity (Table 3). All of the tolerance values exceed 0.1 and the VIF result is below 10. The result indicates that multicollinearity does not pose a serious problem and follows a normal distribution (Table 4). The DurbinWarson statistic is 1.939 which is within the acceptable range of 1.5 to 2.5 (Coake et al. 2003). The result shows that each error problem is independent and no autocorrelation problems are detected within the regression model. Based on Table 5, the result of the ANOVA test is significant $(\mathrm{F}=29.77 ; \mathrm{p}<0.000)$ and reveals a good fit between the data and regression model. Table 6 shows the result of multiple regression analysis to test the hypotheses in this study. 
Table 3. Descriptive Statistics and Inter-Correlations

\begin{tabular}{cccccccc}
\hline & \multirow{2}{*}{ Mean } & \multirow{2}{*}{ SD } & \multicolumn{7}{c}{ Correlations } \\
\cline { 3 - 8 } & & & IB & EEP & EEA & LoS & GPA \\
\hline IB & 76.41 & 8.663 & 1 & .629 & .532 & -.065 & .016 \\
EEP & 79.97 & 8.923 & .629 & 1 & .748 & .032 & -.009 \\
EEA & 53.49 & 7.668 & .532 & .748 & 1 & -.043 & -.171 \\
LoS & 4.99 & 1.330 & -.065 & .32 & -.043 & 1 & .025 \\
GPA & 3.97 & .534 & .012 & -.007 & -.157 & .021 & 1 \\
\hline
\end{tabular}

Note: IB (Innovative Behavior), EEP(Entrepreneurship Education Pedagogic), EEA(Entrepreneurship Education Alternative), LoS (Level of Semester), GPA (Grade Point Average).

Table 4. The Multicollinearity Test

\begin{tabular}{lcccc}
\hline \multicolumn{5}{c}{ Correlations } \\
\hline & EEP & EEA & LoS & GPA \\
\hline Tolerance & .422 & .410 & .989 & .938 \\
VIF & 2.367 & 2.440 & 1.011 & 1.066 \\
\hline
\end{tabular}

Table 5. The Result of ANOVA Test

\begin{tabular}{llllll}
\hline Model & $\begin{array}{l}\text { Sum of } \\
\text { Square }\end{array}$ & df & $\begin{array}{l}\text { Mean } \\
\text { Square }\end{array}$ & F & Sig \\
\hline Regression & 5379 & 4 & 1344 & 29.77 & .000 \\
Residual & 7679 & 170 & 45 & & \\
Total & 13058 & 174 & & & \\
\hline
\end{tabular}

Table 6. The result of multiple regression

\begin{tabular}{lcccccc}
\hline \multirow{2}{*}{ Predictor } & \multicolumn{2}{c}{ Unstandardized Coefficients } & Standardized $\beta$ & T & Sig & Result \\
\cline { 2 - 3 } Coefficients & & & & \\
\hline Constant & \multicolumn{1}{c}{ SE } & 6.674 & & 3.905 & 0 & \\
EEP & 26.063 & 0.88 & 0.532 & 5.779 & 0 & Significant \\
EEA & 0.508 & 0.104 & 0.145 & 1.583 & 0.115 & Not Significant \\
\hline R & 0.164 & 0.642 & & & & \\
R Square & & 0.412 & & & & \\
Adjusted R Square & & 0.398 & & & & \\
\hline
\end{tabular}

Table 6 shows that entrepreneur education based on pedagogic and alternative approach had a relatively strong correlation to the innovative behavior since it had an R-value of 0.642 or $64.2 \%$. The adjusted $\mathrm{R}$ square shows that all variables tested had an impact on student's innovative behavior with the magnitude of $39.8 \%$ and the remaining was affected by other variables not explored in this research. Table 7 shows the measurement of before and after using control variables to assess variables. From the results of the different tests above, it is concluded that there is no difference between the level of the semester and the achievement index (GPA) of entrepreneurial education using a pedagogic approach on innovative behavior. The different results show that there is a difference between the level of the semester and the GPA of entrepreneurial education using alternative approach on innovative behavior.

\section{Level of Semester and GPA as a Determinant for Entrepreneurship Education Model}

From the test of the control variable using the level of semester and GPA, it can be concluded that there is no difference between the semester level and GPA of the influence of entrepreneurial education using the pedagogic approach on innovative behavior due to significance below 0.05 . This result different from entrepreneurial education using an alternative approach that affects innovative behavior. This fact shows, although its popularity in the Indonesian higher education system that pedagogic approach in entrepreneurship curriculum, either the students in a lower semester or with a lower GPA, they believe in assuming the successes of this model is not accepted. 
Table 7 . The result of control variable

\begin{tabular}{lllll}
\hline Control Variable & & Before & After & Result \\
\hline EEP & LoS & .248 & .376 & No significant difference \\
& GPA & .681 & .673 & \\
\multirow{2}{*}{ EEA } & LoS & .851 & .865 & Significant difference \\
& GPA & .012 & .010 & \\
\hline
\end{tabular}

*Significance level $>0.05$

Meanwhile, if the university promotes the cognitive model as proposed by the alternative entrepreneurship model in which integrates the complexity of the learning process, the higher level of their semester, the better they perceived that this model could work better. On the other hand, the higher the GPA of the students also determined the switching of the model to the cognitive way of entrepreneurship model. This is in line with several studies conducted in developing countries such as Bernstein (2011) in which conclude that entrepreneurs could be created along with the intervention of the cognitive model of learning. In order to develop entrepreneurial competencies, learners must participate in entrepreneurial activities and engage in entrepreneurial processes to gain experiential knowledge (Lackéus et al. 2016).

\section{Impact of Entrepreneur Education (Pedagogic Approach) on Innovative Behavior}

The result of the study shows that entrepreneur education based on the pedagogic approach significantly affects innovative behavior. These findings could confirm that instead of using an alternative model which in many developing countries proven to be more effective, the situation in Indonesia may be different. This has been a long process that pedagogy in entrepreneurship education should use an approach that encourages adventure, exploration, and continuous search (Abduh et al. 2012). Entrepreneurship education applied in higher education can give a positive emphasis on attitudes and innovation (Purusottama and Akbar, 2019). In Indonesia, this emphasis is reflected toward an effort so that students are capable and appreciate and understand and foster entrepreneurial interest. Entrepreneurship education should focus on changing student mindset and beliefs toward entrepreneurship intention and behavior (Wibowo, 2019). Management education in some aspects is different from entrepreneurs with a business education that emphasizes management activities that are oriented towards fulfilling human resources to become the manager and the director in a company.
Important insights have been provided by pedagogical methods about how to organize entrepreneurship education in higher education (Hägg and Kurczewska, 2020). Many researchers have criticized conventional pedagogical methods that use teacher-centered learning styles to overemphasize theory and conceptual thought (Collins and Robertson, 2003). However, the study reveals that the pedagogy approach in entrepreneurship education still is proven in lifting innovative behavior. Cruz et al.(2009) research resulted that entrepreneurship education has a direct and positive impact on innovation behavior. This relationship means that students who are interested in seeking further education and entrepreneurship are more pleased with its actions due to innovative behavior. This may be reflected in the current trend of the delivery of courses in Indonesian universities that mostly using the pedagogic approach in teaching and learning methods.

\section{Impact of Entrepreneur Education (Alternative Approach) on Innovative Behavior}

The empirical data also showed that an alternative approach in entrepreneurship education that emphasizes the cognitive model of learning, as it is perceived by the students still not proven to lift the innovative behavior. This indicates that an approach that has been tested in developed countries cannot simply be applied in Indonesia The results show that compared to alternative entrepreneurship education that has been successfully implemented in developed countries since two decades ago, from the scope of the sample studied in this study, it is precisely the pedagogic model of entrepreneurship education that is still the preferred by the students and it is believed to be able to foster a culture of innovation. This transformation can lead to better entrepreneurial behavior and entrepreneurial thinking (Bell and Bell, 2020). This fact is very basic because if we flashback to the curriculum that is generally introduced in Indonesia today, especially in universities, it is still in the transition from andragogy to pedagogy. Students' perceptions of alternative entrepreneurship education are still not fully accepted by students due to several factors, for 
example, the level of risk that may be culturally very reasonable where Indonesian people generally tend to avoid risk. Although this study offers a significant contribution to alternative entrepreneurship education in higher education, some limitations should be noted. First, we used only students from two-semester and in three big universities in Malang, while for future studies the selection of the sample could be wider. Second, we only posed two control variables, where appropriate in the future variables like the students' experiences in doing business could be incorporated in the model.

\section{Managerial Implication}

The results of this study are expected to provide an overview for decision-makers especially in the higher education sector to start implementing entrepreneurship education with different methods as an effort to improve graduates innovative behavior, especially for generation $Z$. Through a different approach to entrepreneurship education, it is hoped that generation $\mathrm{Z}$ in the future will gain broader insights, open up their traditional mindset, and can make entrepreneurship education not only provide tactical but also non-practical experience.

\section{CONCLUSIONS AND RECOMMENDATIONS}

\section{Conclusions}

The study reveals many potential aspects, one of that the entrepreneurship education with an alternative approach does not have a significant effect on innovative behavior. This indicates that an approach that has been tested in developed countries cannot simply be applied in Indonesia. What is important to look after that to stimulate innovative behavior in entrepreneurship education, the pedagogic entrepreneurship education is more dominant than alternative approaches to innovative behavior. This indicates that a very familiar pedagogic model is well accepted by students, especially when it comes to entrepreneurship education where the potential for forming innovative behavior is more visible.

\section{Recommendations}

Seeing the massive slogans of integrated education where universities require an entrepreneurial nuanced college curriculum, it is necessary to strengthen the contemporary pedagogical education model by raising the issue of the industrial revolution 4.0 It is obtained empirical facts that the alternative entrepreneurship education model is felt to be accepted by upperlevel students, so that along with the introduction of entrepreneurship education, it is presumably for universities to move the model from pedagogic to alternative. Empirically this research provides a new color for the integration of entrepreneurship education models so that in the future it is suggested that research be carried out in a wider scope.

\section{REFERENCES}

Abduh M, Maritz A, Rushworth S. 2012. An evaluation of entrepreneurship education in Indonesia: Acase study of Bengkulu University. The International Journal of Organizational Innovation 4(4): 4243.

Bernstein A. 2011. Nature vs. nurture: Who is interested in entrepreneurship education? A study of business and technology undergraduates based on social cognitive career theory [dissertation]. Washington: The George Washington University.

Bell R, Bell H. 2020. Applying educational theory to develop a framework to support the delivery of experiential entrepreneurship education. Journal of Small Business and Enterprise Development 27(6):987-1004.https://doi.org/10.1108/ JSBED-01-2020-0012.

Collins A, Robertson M. 2003. The entrepreneurial summer school as a successful model for teaching enterprise. Education + Training 45(6): 324-330. https://doi.org/10.1108/00400910310495978.

Cruz et al. 2009. The effect of entrepreneurship education programmes on satisfaction with innovation behaviour and performance. Journal of European Industrial Training 33(3): 198-214. https://doi.org/10.1108/03090590910950578.

FayolleA, Gailly B.2015.Theimpactofentrepreneurship education on entrepreneurial attitudes and intention: Hysteresis and persistence. Journal of Small Business Management 53(1): 75-93. https://doi.org/10.1111/jsbm.12065.

Fayolle A, Gailly B, Lassas-Clerc N. 2006. Assessing the impact of entrepreneurship education programmes: A new methodology. Journal of European Industrial Training 30(9): 701-720. https://doi.org/10.1108/03090590610715022.

Hägg G, Kurczewska A. 2020. Guiding the student 
entrepreneur - Considering the emergent adult within the pedagogy-andragogy continuum in entrepreneurship education. Education and Training 62(7-8): 759-777. https://doi. org/10.1108/ET-03-2020-0069.

Hair et al. 2014. Multivariate Data Analysis (7 edition). London: Pearson Education Limited.

Harris S, Forbes T, Fletcher M. 2000. Taught and enacted strategic approaches in young enterprises. International Journal of Entrepreneurial Behaviour and Research 6(3): 125-145. https:// doi.org/10.1108/13552550010346217.

Lackéus M, Lundqvist M, Middleton KW. 2016. Bridging the traditional progressive education rift through entrepreneurship. International Journal of Entrepreneurial Behavior and Research 22(6):777-803.

Lewrick $M$ et al. 2011. Education for entrepreneurship and innovation: Management capabilities for sustainable growth and success. World Journal of Entrepreneurship, Management and Sustainable Development 6(1/2): 1-18. https:// doi.org/10.1108/20425961201000001.

LourençoF, Jones O. 2006. Developing entrepreneurship education: comparing traditional and alternative teaching approaches. International Journal of Entrepreneurship Education 4(1): 111-140.

Purusottama A, Akbar T F. 2019. An Entrepreneurship Education Model for Promoting Students' Entrepreneurial Intentions: The Case of Indonesian Higher Education. Indonesian Journal of Business and Entrepreneurship 5(2):138-147.https://doi.org/10.17358/ ijbe.5.2.138.

Saji BS, Nair AR. 2018. Effectiveness of innovation and entrepreneurship education in UAE higher education. Academy of Strategic Management Journal 17(4): 1-12.

Shaw E. 2004. Marketing in the social enterprise context: Is it entrepreneurial? Qualitative Market Research:AnInternationalJournal7(3): 194-205. https://doi.org/10.1108/13522750410540209

Souitaris V, Zerbinati S, Al-Laham A. 2007. Do entrepreneurship programmes raise entrepreneurial intention of science and engineering students? The effect of learning, inspiration and resources. Journal of Business Venturing 22(4): 566-591. https://doi. org/10.1016/j.jbusvent.2006.05.002.

Sterling S. 2001. Sustainable Education: Re-visioning Learning and Change. UK: Green Books.

Van Gelderen et al. 2008. Explaining entrepreneurial intentions by means of the theory of planned behaviour. Career Development International 13(6): 538-559. https://doi. org/10.1108/13620430810901688

Vanevenhoven J, Liguori E. 2013. The impact of entrepreneurship education: introducing the entrepreneurship education project. Journal of Small Business Management 51(3): 315-328. https://doi.org/10.1111/jsbm.12026.

Wibowo B. 2019. Spirituality, entrepreneurship education and entrepreneurial intention among moslem undergraduate students: spiritual wellbeing scaling application. Indonesian Journal of Business and Entrepreneurship 5(2): 118-128. https://doi.org/10.17358/ijbe.5.2.118.

Wright LK, Bitner MJ, Zeithaml VA. 1994. Paradigm shifts in business education: using active learning to deliver services marketing content. Journal of Marketing Education 16(3): 5-19. 